\title{
Glucose metabolism in isolated uteri of immature rats. Influence of prostaglandins and nitric oxide
}

\author{
Ana Beatriz FINKELBERG*, Jorge LinARES, Adolfo GOLDRAIJ \\ Cátedra de Fisiología, Facultad de Odontología, Universidad Nacional de Córdoba, Córdoba, Argentina
}

(Received 2 February 2005; accepted 24 May 2005)

\begin{abstract}
We studied the contractile activity and glucose metabolism, in terms of production of ${ }^{14} \mathrm{CO}_{2}$ from $\left[{ }^{14} \mathrm{C}\right]$ glucose, in isolated uteri of immature rats. Immaturity was due to age or exposure to a restricted diet. The contractile activity in both prepubertal groups persisted for a period of 60 minutes and fell when indomethacin was added to the KRB medium. The production of ${ }^{14} \mathrm{CO}_{2}$ was greater than for adult rats and fell as a result of the addition of indomethacin. The metabolism of $\left[{ }^{14} \mathrm{C}\right]$ arachidonic acid showed that the percentage of eicosanoids released in age related immature uteri was greater than that in restricted diet related immature uteri. In animals that are immature as a result of exposure to a restricted diet, ${ }^{14} \mathrm{CO}_{2}$ fell due to the effect of NAME. Sodium nitroprusside and L-arginine increased the production of ${ }^{14} \mathrm{CO}_{2}$. This effect was reverted by NAME and indomethacin. Conversely, the uteri of age related prepubertal rats were not affected. The level of activity of nitric oxide synthase was higher in restricted diet related immature animals and fell following the addition of NS-398. We may conclude that in rats exposed to a restricted diet, NO and COX-2 participate in glucose metabolism whereas they would not be involved in age related prepubertal animals.
\end{abstract}

immature rats / glucose metabolism / nitric oxide / arachidonic acid

\section{INTRODUCTION}

Previous studies by our laboratory showed that glucose metabolism in isolated uteri of adult rats undergoes a significant reduction if the animal is previously exposed to a prolonged restricted diet [1-3]. Conversely, in immature rats, a restricted diet delays sexual maturity but fails to affect glucose metabolism [4].

It is known that the derivatives of arachidonic acid influence the metabolism of carbohydrates [1-3, 5] and that prostaglandin E controls the uterine activity of immature rats [6]. Furthermore, nitric oxide (NO), synthesized from arginine by nitric oxide synthase (NOS) is involved in numerous physiological processes [7], amongst which lies glucose metabolism [8,9]. In a previous study on fasting rats we demonstrated that inhibitors of NOS prevent the increase of glucose metabolism induced by indomethacin [9]. Within this context, the aim of the present study was to analyze glucose metabolism and its participation as an energetic source to sustain contractile activity in the isolated uteri of immature rats whose immaturity stems from the following: (i) physiological conditions due to their age or (ii) exposure to a restricted diet. In particular, we explored the differences between these two groups in terms of the participation of

\footnotetext{
* Corresponding author: fink@odo.unc.edu.ar
} 
prostaglandins (PG) and the nitric oxide system.

\section{MATERIALS AND METHODS}

\subsection{Animal and tissue preparations}

Female immature Wistar rats were used throughout the study. They were individually housed in metabolic cages and kept in a temperature and illumination controlled room (photoperiod: $14 \mathrm{~h}$ light and $10 \mathrm{~h}$ darkness). These females had their first estrous cycle at an average of $37.0 \pm 2.3$ (mean \pm SD) days of age. At 21 days of age, the animals were weighed and assigned to different groups: (i) Immature rats with free access to a normal diet (Cargill-Argentina), during an experimental period of 10 days. This group comprised sexually immature animals due to age. (ii) Immature rats subjected to a restricted diet, i.e. $50 \%$ of normal food intake over a period of 25 days. This treatment totally blocked reproductive development and the rats were in a permanent immature state. (iii) Mature rats (2 month), with free access to a normal diet (CargillArgentina), used in the diestrus period. (i.v.) Mature rats subjected to a restricted $\operatorname{diet}(50 \%$ of the normal intake) for 25 days. These rats were in permanent diestrus.

All the groups had free access to tap water. The rats were killed by decapitation. Their uterine horns were excised, dissected and transferred to Petri dishes containing a Krebs-Ringer-bicarbonate solution (KRB), with $95 \% \mathrm{O}_{2}, 5 \% \mathrm{CO}_{2}$. The ionic composition of this medium has been reported elsewhere [10].

\subsection{Contractile activity: isometric developed tension}

The uterine horns were excised, dissected and suspended in a tissue chamber filled with $\mathrm{KRB}$ medium gassed and maintained at $37{ }^{\circ} \mathrm{C}$ and a pH of 7.4. One end of the horn was anchored to a stationary glass holder and the other to a strain gauge. The preparation was then subjected to a resting tension of $500 \mathrm{mg}$ by means of a micromet- ric device. The Isometric developed tension (IDT), in $\mathrm{mg}$, was recorded with the aid of a direct-ink writing kymograph. The spontaneous contractions of the isolated uterus were recorded during $60 \mathrm{~min}$. The values of IDT detected during the first 10 min after isolation and mounting, were considered as initial internal control. The variation in the mean values of IDT recorded at the end of the experimental period were expressed as the percentage of the initial control value.

\subsection{Determination of glucose oxidation}

The procedure was based on the production of the ${ }^{14} \mathrm{CO}_{2}$ released by the oxidation of $\left[\mathrm{U}^{14} \mathrm{C}\right]$ glucose. The tissue was cut in strips and immersed in Warburg flasks containing $1.0 \mathrm{~mL} \mathrm{KRB}$. In the center well, small pieces of filter paper soaked in benzethonium hydroxide were used to trap the released ${ }^{14} \mathrm{CO}_{2}$. The flasks were incubated at $37{ }^{\circ} \mathrm{C}$ for $15 \mathrm{~min}$ and, at the end of this period $10.0 \mu \Lambda$ of $\left[\mathrm{U}^{14} \mathrm{C}\right]$ glucose $\left(1.0 \mu \mathrm{Ci} \cdot \mathrm{mL}^{-1}\right)$ were added. Immediately after, the flasks were sealed and incubated in a Dubnoff metabolic shaker for $2 \mathrm{~h}$. At the end of this period, the reaction was stopped with $\mathrm{H}_{2} \mathrm{SO}_{4}(18 \mathrm{~N})$, and the ${ }^{14} \mathrm{CO}_{2}$ was trapped during 120 min under shaking. The radioactivity of each filter paper was then determined by liquid scintillation counting and the results were expressed as $\mu \mathrm{Ci} \cdot \mathrm{mg}^{-1}$ dry tissue weight.

\subsection{Metabolism of $\left[{ }^{14} \mathrm{C}\right]$ arachidonic acid}

The metabolism of the exogenous arachidonic acid in different groups of rat uterine tissue was explored by incubating, for $60 \mathrm{~min}$, approximately $200 \mathrm{mg}$ of the uterine segment in $\mathrm{KRB}$ buffer containing $0.25 \mathrm{uCi}$ of $\left[{ }^{14} \mathrm{C}\right]$ arachidonic acid $\left(56 \mathrm{uC} \cdot \mathrm{mol}^{-1}\right)$, in a metabolic shaking bath under an atmosphere of $95 \% \mathrm{O}_{2}, 5 \% \mathrm{CO}_{2}$. The lipids were extracted to silica-gel thin-layer chromatography (TCL) plates. Radioactivity from the TCL zones of the specific arachidonic acid and of different eicosanoids (6-keto$\mathrm{PgF}_{1 \alpha}, \mathrm{PgE}_{2}, \mathrm{PgF}_{2 \alpha}$, and $\mathrm{TXB}_{2}$ ) were measured by liquid scintillation counting. 
Table I. Initial isometric developed tension (IDT) and constancy with time of the spontaneous contractions of isolated uterine strips of immature rats due to their age (INF) or to a restricted diet (IRD).

\begin{tabular}{lccc}
\hline Experimental condition & Addition to KRB medium & $\begin{array}{c}\text { Initial IDT } \\
\mathrm{mg}^{-1} \mathrm{mg} \mathrm{d} . \mathrm{w}\end{array}$ & $\begin{array}{c}\text { IDT (60 min) } \\
\% \text { of change }\end{array}$ \\
\hline Immature normal feeding & None & $298 \pm 31.2$ & $-22.8 \pm 8.3$ \\
(INF) & Indomethacin & $324 \pm 34.3$ & $-62.2 \pm 7.4^{* *}$ \\
Immature restricted diet & None & $320 \pm 29.1$ & $-34.6 \pm 5.9$ \\
(IRD) & Indomethacin & $352 \pm 34.7$ & $-79.4 \pm 8.6^{* *}$ \\
\hline
\end{tabular}

Mean \pm SEM of $9-10$ cases. $* * P<0.01:$ KRB + Indomethacin vs. KRB.

The areas of the radiopeaks corresponding to the authentic eicosanoids were calculated and expressed as a percentage of the total radioactivity of the plates.

\subsection{Determination of NOS activity}

A modification of the method of Brendt and Snayder that measures the conversion of ${ }^{14} \mathrm{C}$ arginine into $\left[\mathrm{C}^{14}\right]$ citrulline was used. The method indirectly measures NO production, an index of NOS activity [11].

\subsection{Drugs}

The first group of experiment was carried out to analyse contractile activity and production of ${ }^{14} \mathrm{CO}_{2}$ from $\left[\mathrm{U}^{14} \mathrm{C}\right]$ glucose in a KRB medium or in KRB medium with the addition of indomethacin $\left(5 \times 10^{-6} \mathrm{M}\right)$ alone or with prostaglandin $(\mathrm{Pg}): \mathrm{PgE}_{1}$, $\mathrm{PgE}_{2}$ or $\mathrm{PgF}_{2 \alpha}$. Subsequently, we analysed the effect of N $\omega$ nitro-L-arginine methyl ester (NAME), $500 \mu \mathrm{M}$; sodium nitroprusside (SNP), $400 \mu \mathrm{M}$ and L-arginine, benzethonium hydroxide, $1 \mathrm{mM}$ (Sigma Chemical Co., St. Louis, Mo, USA) over ${ }^{14} \mathrm{CO}_{2}$ from $\left[\mathrm{U}^{14} \mathrm{C}\right]$ production. Another group of experiments was carried out adding $30 \mu \mathrm{M}$ of NS-398 (Caiman, Ann Arbor, Mi, USA) to verify the effect on NOS activity. $\left[\mathrm{U}^{14} \mathrm{C}\right]$ glucose and $\left[\mathrm{C}^{14}\right]$ arachidonic acid were obtained from New England Nuclear. All concentrations quoted represent the final concentrations in the suspension solution.

\subsection{Statistics}

All the results in the text, tables and figures are presented as means \pm SEM. The statistical significance of differences between mean values was assessed using the twotailed Student $t$-test. Differences were considered significant when $P=0.05$ or less.

\section{RESULTS}

Table I shows that strips of the uterus isolated from age or restricted diet related immature rats did not exhibit statistically significant differences in initial isometric tension or in stability over the $60 \mathrm{~min}$ of the experimental period. The addition of indomethacin to the culture medium elicited a significant reduction in the contractile activity in both experimental groups.

Table II shows the production of ${ }^{14} \mathrm{CO}_{2}$ from $\left[\mathrm{U}^{14} \mathrm{C}\right]$ glucose in uteri isolated from rats submitted to different treatments. The data show that uteri isolated from age related immature rats and restricted diet related immature rats exhibited similar levels of ${ }^{14} \mathrm{CO}_{2}$ production. In both immature groups, the ${ }^{14} \mathrm{CO}_{2}$ production was significantly greater $(P<0.01)$ than that of the adult animals. Conversely to prepubertal animals, there was a significant reduction in glucose metabolism in the uteri of adult animals on a restricted diet as compared to normofed control adults $(P<0.05)$.

The possible participation of $\mathrm{PG}$ in the rise in glucose metabolism in both groups of immature rats is analyzed in Figure 1. 


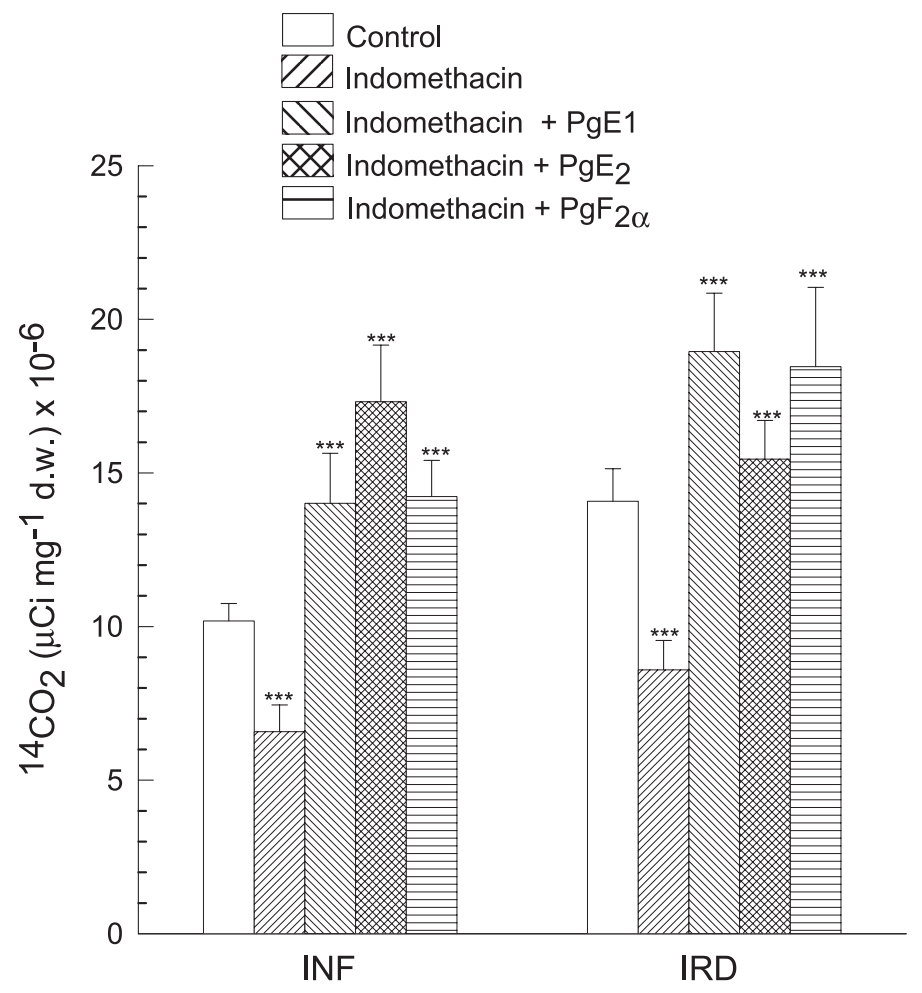

Figure 1. Formation of ${ }^{14} \mathrm{CO}_{2}$ from $\left[\mathrm{U}^{14} \mathrm{C}\right]$ glucose in isolated uterine strips (KRB medium) of immature rats due to their age (INF) or to a restricted diet (IRD). Effect of indomethacin $5 \times 10^{-6} \mathrm{M}$ and prostaglandins. Mean \pm SEM of $10-12$ cases. $* * * P<0.001$ : Indomethacin vs. control; indomethacin $+\operatorname{PgE}_{1}, \operatorname{PgE}_{2}$ and $\operatorname{PgF}_{2 \alpha}$.

Table II. Formation of ${ }^{14} \mathrm{CO}_{2}$ from $\left[\mathrm{U}^{14} \mathrm{C}\right]$ glucose in isolated uterine strips (KRB medium) of mature and immature rats due to their age or to a restricted diet.

\begin{tabular}{cc}
\hline Experimental condition & ${ }^{14} \mathrm{CO}_{2}(\mu \mathrm{Ci} \mathrm{mg} \mathrm{dw}) \times 10^{-6}$ \\
\hline $\begin{array}{c}\text { Immature normal feeding } \\
\text { (INF) }\end{array}$ & $13.03 \pm 0.98^{* *}$ \\
$\begin{array}{c}\text { Immature restricted diet } \\
\text { (IRD) }\end{array}$ & $\left.15.42 \pm 1.25^{* *}\right)$ \\
$\begin{array}{c}\text { Mature normal feeding } \\
\text { (MNF) }\end{array}$ & $6.86 \pm 0.53$ \\
$\begin{array}{c}\text { Mature restricted diet } \\
(\text { MRD) }\end{array}$ & $4.89 \pm 0.56^{*}$ \\
\hline Mean + SEM of $10-11$ cases. $* * P<0.01:$ INF and IRD vs. MNF and MRD. $* P<0.05:$ MRD vs. MNF.
\end{tabular}

The production of ${ }^{14} \mathrm{CO}_{2}$ from $\left[\mathrm{U}^{14} \mathrm{C}\right]$ glucose in isolated uteri from both groups of immature rats was significantly diminished by the presence of indomethacin. The exogenous addition of $\mathrm{PgE}_{1}, \mathrm{PgE}_{2}$ or $\mathrm{Pg} \mathrm{F}_{2 \alpha}$, reverted the action of indomethacin. 


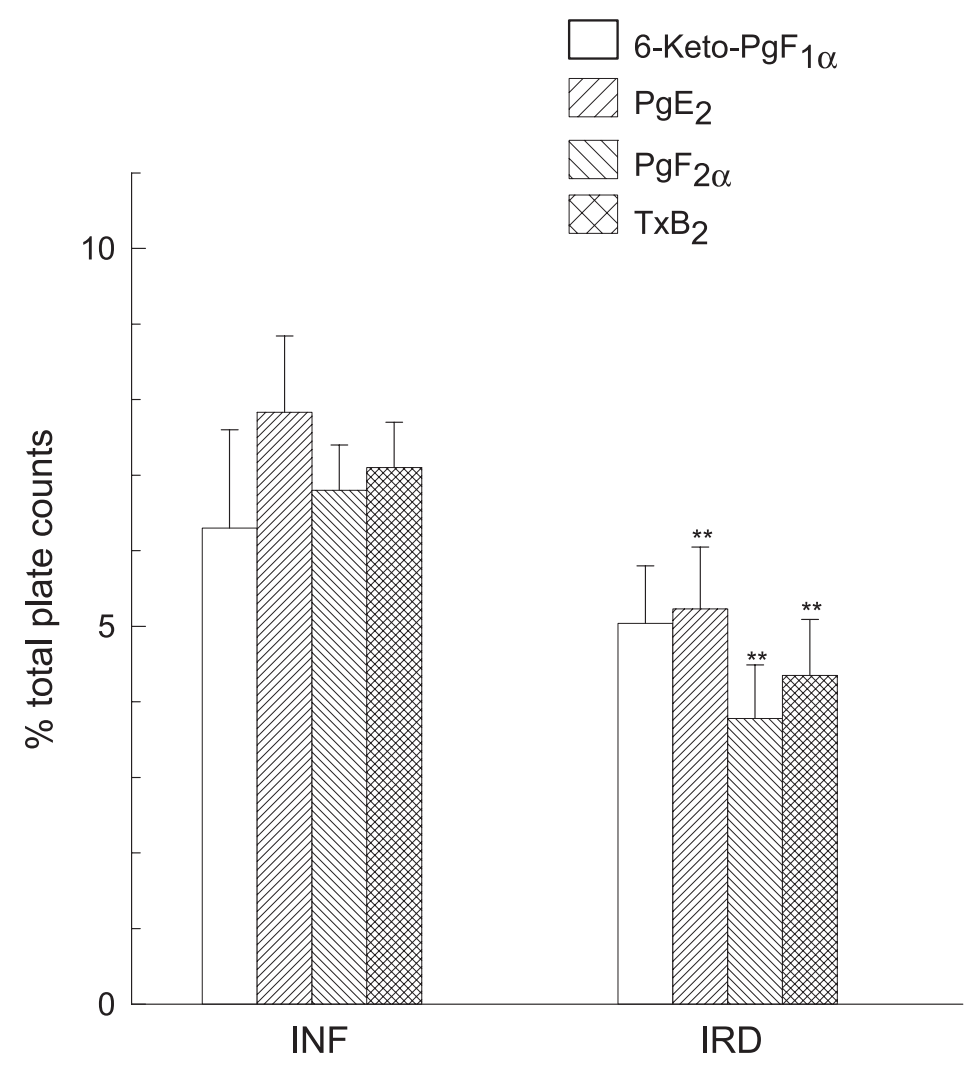

Figure 2. Eicosanoid production from $\left[{ }^{14} \mathrm{C}\right]$ arachidonic acid of isolated uterus from immature rats due to their age or to a restricted diet. Mean \pm SEM of $10-12$ cases. $* * P<0.01: \mathrm{PgE}_{2}, \mathrm{PgF}_{2 \alpha}$ and $\mathrm{TxB}_{2}$ (immature restricted diet vs. age).

Figure 2 shows the analysis of the production of different metabolites of arachidonic acid. The production of $\mathrm{PgE}_{1}, \mathrm{PgE}_{2}$, $\mathrm{PgF}_{2 \alpha}$ and $\mathrm{TXB}_{2}$ was significantly reduced in the immature restricted diet as compared to age related immature rats.

Figure 3 shows the effect of different agents related to the arginine-nitric oxide system on the metabolism of glucose in prepubertal rats. In age related immature rats, the addition of L-NAME, an inhibitor of NOS, did not affect glucose metabolism. The addition of arginine, a NOS substrate, or of sodium nitroprusside (SNP), an exog- enous donor of nitric oxide, did not affect glucose metabolism either.

Conversely, in restricted diet related immature rats, antagonists of nitric oxide such as L-NAME, reduced the metabolism of $\left[\mathrm{U}^{14} \mathrm{C}\right]$ glucose, whereas the addition of arginine and sodium nitroprusside increased the production of ${ }^{14} \mathrm{CO}_{2}$ significantly. The stimulating action of arginine was reverted by indomethacin, a non-specific inhibitor of cyclooxygenase, or by NAME.

Table III shows that NOS activity was significantly greater in the uteri of restricted diet related immature rats and that NS-398, 


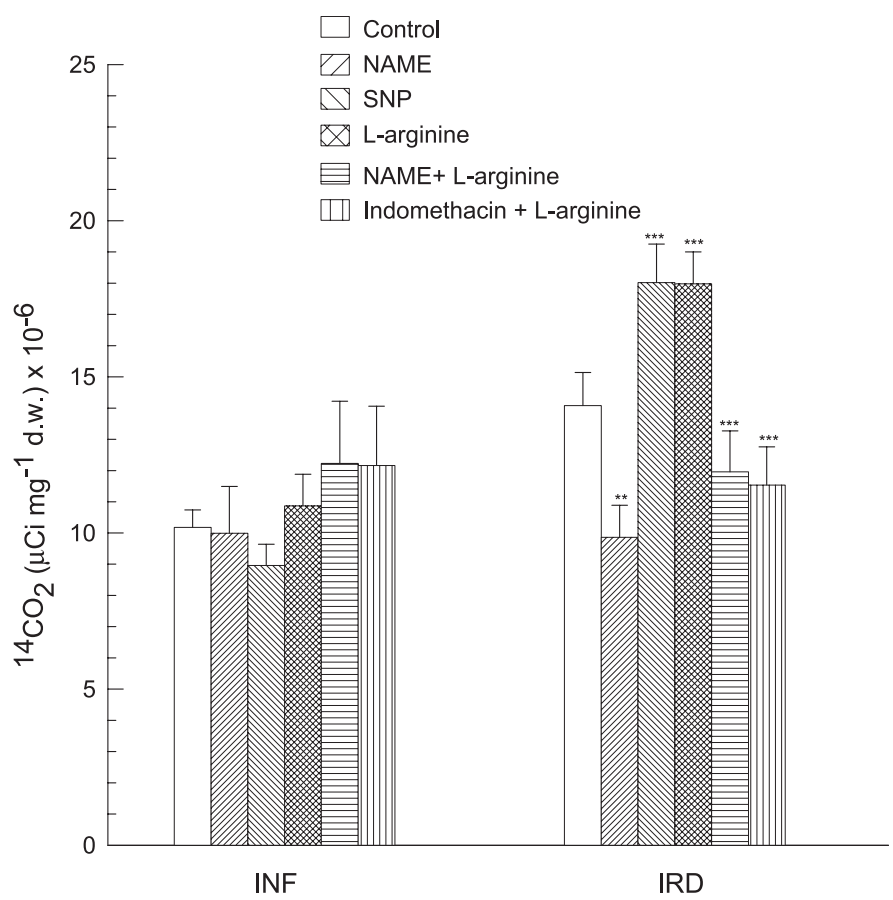

Figure 3. Formation of ${ }^{14} \mathrm{CO}_{2}$ from $\left[\mathrm{U}^{14} \mathrm{C}\right]$ glucose in isolated uterine strips of immature rats due to their age or to a restricted diet. Effect of indomethacin, NAME (N $\omega$-nitro-L-arginine methyl ester), L-arginine and sodium nitroprusside (SNP). Mean \pm SEM of $10-12$ cases. $* * P<0.01$ : NAME vs. Control; *** $P<0.001$ : SNP and L-arginine vs. control; NAME + L-arginine vs. NAME; indomethacin $+\mathrm{L}$-arginine vs. L-arginine.

Table III. Activity of NOS in the isolated uteri of immature rats.

\begin{tabular}{lcc}
\hline Experimental condition & \multicolumn{2}{c}{ NOS activity $\left(\mathrm{cpm}^{\mathrm{m}} \mathrm{mg}^{-1} \mathrm{dw}\right)$} \\
\cline { 2 - 3 } & $\mathrm{BASAL}$ & $\mathrm{NS}-398$ \\
\hline Immature normal feeding (INF) & $3561 \pm 349$ & $4066 \pm 389$ \\
Immature restricted diet (IRD) & $5624 \pm 652 * *$ & $2934 \pm 172 * *$ \\
\hline
\end{tabular}

Mean \pm SEM of 8-10 cases. ** $P<0.01$ : Basal IRD vs. INF; NS-398 IRD vs. INF.

a selective inhibitor of $\mathrm{COX}-2$, reduced NOS activity significantly. However, it failed to exert any effect on the uteri of age related immature rats.

\section{DISCUSSION}

It is well known that several metabolic and hormonal factors affect the spontaneous contractile activity of the isolated uterus [12]. The present study shows that the two groups of uteri of immature rats under study exhibited a similar basal activity and a persistent activity during the whole experimental period. These findings were in agreement with those of other authors [6] who described an increase in the contractile activity in the uteri isolated from immature rats. 
Glucose metabolism is central to the functional activity of the uterus. The present study confirmed previous findings [4] that revealed a higher level of glucose metabolism in the isolated uteri of prepubertal animals as compared to those of adult rats. Surprisingly, whereas a restricted diet elicited a dramatic reduction in uterine glucose metabolism in adult rats, it failed to affect the glucose metabolism of immature rats. This finding may be attributed to the fact that during the stages that precede sexual maturity there is an increase in storage and utilization of glucose associated to enhanced sensitivity to insulin [13]. Since the main source of energy to sustain uterine motility came from glucose metabolism, it is important to address that both groups of immature animals examined herein exhibited a rise in glucose metabolism and uterine motility.

Indomethacin elicits a significant fall in uterine motility associated to a reduction in glucose metabolism. This effect is reverted by the addition of exogenous PG. These data confirmed the capacity of PG to stimulate motility and glucose metabolism in the isolated uteri of rats. This stimulatory action was in agreement with previous findings of our laboratory in adult animals [14, $15,17]$ and of other authors [16]. The data described herein showed that the isolated uterus converts $\left[\mathrm{C}^{14}\right]$ arachidonic acid to different eicosanoids: $\mathrm{PgE}_{2}, \mathrm{PgF}_{2 \alpha}$, 6-keto$\mathrm{PgF}_{1 \alpha}$ (indicating the production of $\mathrm{PgI}_{2}$ ) and $\mathrm{TXB}_{2}$ (indicating the production of $\mathrm{TXA}_{2}$ ) in both groups of immature rats. However, the percentage of eicosanoids $\mathrm{PgE}_{2}, \mathrm{PgF}_{2 \alpha}$ y $\mathrm{TXB}_{2}$, was significantly lower in the uteri of restricted diet related immature rats.

These results suggest that our experimental groups have differences related to prostaglandin activity and its influence upon glucose metabolism.

A new set of experiments were performed to identify some signaling cascades involved in the metabolic effect of immature restricted diet rats. Other authors [18-
19] pointed out that the biosynthesis of $\mathrm{Pgs}$ seems to be modulated by the arginine-NO pathway.

We studied the participation of agonists and antagonists of the NO system in glucose homeostasis in the isolated uteri of immature rats employing glucose production.

Pgs are known to play an important role in different physiological functions and are produced by the conversion of arachidonic acid into an intermediary product such as prostaglandin $\mathrm{H}_{2}$, catalyzed by COX. Furthermore, NO plays an important role in the regulation of COX. There are two isoforms of the COX enzyme, COX-1 and COX-2. Normal physiological functions are mediated by the constitutive form COX-1, whereas the other functions are mediated by the inducible form. A close association has been described between $\mathrm{Pg}$ biosynthesis and the arginine-NO pathway [18-20].

In restricted diet related immature rats NAME elicited a fall in the production of ${ }^{14} \mathrm{CO}_{2}$. Addition of L-arginine, the substrate for the production of NO, to the KRB medium, significantly stimulated glucose metabolism. This effect was reverted by the addition of NAME and indomethacin. Furthermore SNP, a yielded exogenous NO, stimulated glucose metabolism, confirming the findings of other authors [8].

In the age related prepubertal rats studied herein, the addition of NAME failed to affect the glucose metabolism of isolated uteri. The same occurred with the addition of L-arginine, demonstrating that the arginine-nitric oxide pathway would not be involved in the regulation of glucose metabolism.

These data suggest that NOS-COX-2 and $\mathrm{Pgs}$ play a role in restricted diet related prepubertal rats but do not participate in age related immature rats. In this group, the glucose metabolism seems to be regulated by prostaglandins, independently of the argininenitric oxide pathway.

Further investigations will be necessary in order to clarify the complex effects of underfeeding in prepubertal rats. 


\section{ACKNOWLEDGEMENTS}

This work was supported by grants of CONICET (Consejo Nacional de Investigaciones Científicas y Técnicas de la República Argentina), Agencia Cordoba Ciencia and Secyt (Secretaría de Ciencia y Tecnología de la Universidad Nacional de Córdoba)

\section{REFERENCES}

[1] Casalino SM, Finkelberg AB, Linares JA, Goldraij A. Effect of a restricted diet on "in vitro" spontaneous activity, metabolism of labeled glucose and levels of glycogen in isolated rat uteri. Influence of castration. Arch Int Physiol Biochim Biophys 1994, 102: 111114.

[2] Casalino SM, Linares JA, Goldraij A. Different effects of a restricted diet on isolated uteri of ovariectomized and non ovariectomized rats. Influence of indomethacin and prostaglandins. Prostaglandins Leukot Essent Fatty Acids 1994, 51: 41-45.

[3] Casalino SM, Linares JA, Goldraij A. Effects of ovarian steroid on labeled glucose metabolism in uteri isolated from restricted diet rats. Influence of castration. Arch Physiol Biochem 1996, 104: 152-156.

[4] Finkelberg AB, Lanfri-Aguilar N, Goldraij A. Effect of a restricted diet on the metabolism of glucose in uteri isolated from immature rats: influence of indomethacin and nordihydroguaiaretic acid. Prostaglandins Leukot Essent Fatty Acids 1998, 59: 175-179.

[5] Gonzalez ET Gimeno MF Gimeno AL Prostaglandin $\mathrm{E}_{2}$ alters the metabolism of labeled glucose in uteri isolated from ovariectomized rats. Effects of $17 \beta$ estradiol and indomethacin. Prostaglandins Leukot Essent Fatty Acids 1989, 35: 31-35.

[6] Chaud M, Gonzalez ET, Franchi AM, Gimeno MF, Gimeno AL. Sex hormones and the motility of and prostaglandin output from uterine horns of immature rats. Prostaglandins Leukot Essential Fatty Acids 1984, 15: 35-44.

[7] Moncada S, Palmer RMG, Higgs EA. Nitric Oxide: physiology, pathophysiology and pharmacology. Pharmacol Rev 1991, 43: 109-142.

[8] Gonzalez E, Jawerbaum A, Novaro V, Faletti A, Gimeno MAF. The role of nitric oxide in the metabolism of labeled glucose in isolated uterus. Influence of 17- $\beta$ estradiol. Prostaglandins 1995, 50: 225-235.
[9] Campos ML, Casalino-Matsuda SM, Linares JA, Godraij A. Effect of inhibitors of nitric oxide synthase on isolated uteri of fasting rats. Prostaglandins Leukot Essent Fatty Acids 1998, 59: 23-26.

[10] Gimeno AL, Goldraij A, Gimeno MF. Effects of arsenite and oxamate on in vitro functional activity of estrogen-dominated rat uterine horns. Experientia 1979, 35: 221-222.

[11] Lomniczi A, Suburo AM, Elverdin JC, Mastronardi CA, Díaz C, Rettori V, McCann SM. Role of nitric oxide in salivary secretion. Neuroimmunomodulation 1998, 5: 226-233.

[12] Goldraij A, Gimeno AL, Gimeno MF. Metabolic factors involved in the uterine motility of the rat. Acta Physiol Latinoam 1975, 25: 229-232.

[13] Goodman M, Raghavan S, Saenger P, Hu M, Barzilai N. Intracellular pathway of insulinmediated glucose uptake before and after puberty in conscious rats. Pediatr Res 1997 . 41: 340-345.

[14] Casalino SM, Linares JA, Goldraij A. Influence of underfeeding on the spontaneous contraction and on metabolism of labeled arachidonic acid in uteri isolated from intact and ovariectomized rats. Prostaglandins Leukot Essent Fatty Acids 1996, 55: 155-159.

[15] Lopez M, Gonzalez ET, Sterin ABF, Goldraij A. Effect of chronic underfeeding on uterine glycogen of rats. Influence of indomethacin and nordihydroguaiaretic acid. Prostaglandins Leukot Essent Fatty Acids 1991, 43: 87-91.

[16] Campos ML, Linares JA, Goldraij A. Influence of Interleukin $1 \alpha$ over the metabolism of arachidonic acid and glucose in isolated uterus of restricted diet rats. Influence of COX-2. Prostaglandins Leukot Essent Fatty Acids 2004, 70: 17-22.

[17] Beatty CH, Bocek RM. Prostaglandins: Their effect on carbohydrate metabolism of myometrium from Rhesus monkeys. Endocrinol 1972, 90: 1295-1300.

[18] Di Rosa M, Ialenti A, Ianari A, Sautebin L. Interaction between nitric oxide and cyclooxigenase pathways. Prostaglandins Leukot Essent Fatty Acids 1996, 54: 229-238.

[19] Yuan-Lin D, Yallampalli CH. Interaction between nitric oxide and prostaglandin E2 pathways in pregnant rat uteri. Am J Physiol 1996, 270: E471-E476.

[20] Salvemini D. Regulation of cyclooxygenase enzymes by nitric oxide. Cell Mol Life Sci 1997, 53: 576-582. 